\title{
The Pentagon and Basic Science
}

SEveral years have gone since the Department of Defense in the United States was widely and fairly regarded as a source of funds for basic research. Although the scale of expenditure under this heading is still quite large, by standards applicable elsewhere, and will amount to 15 per cent or thereabouts of what the Federal Government does to help basic science, the time is long since past when the armed services were able to support long-term research projects not merely because these were of potential scientific importance but because support of such a kind could be reckoned in the long run to contribute to the strength of American universities, to the supply of skilled people in science and engineering and ultimately to the strategic force of American policies, not merely in military fields but in economic fields as well. No doubt the transformation which there has been is a great comfort to academics embattled with students who are increasingly prepared to boycott lectures if it seems that there is a whiff of involvement with national security, and there are more lasting arguments than that for a permanent shift of the source of support for science to those agencies of government whose job it is to support basic research as such. Yet the transformation which has come about in the past few years is not merely of practical importance in the increasingly taut scramble for funds by American universities and colleges but also raises important questions for societies elsewhere.

Historically, the involvement of the Department of Defense in American science dates from the zeal with which the Office of Naval Research, more than a quarter of a century ago, set out on its unprecedented programme of support for basic science. In retrospect, some of the reasons given for these activities are enough to set a man back on his heels. The zoology of dolphins was, for example, held to be of potential relevance to military affairs by the paper-thin argument that nobody could be sure that isolated dolphin brains would not, in due course, turn out to be more convenient devices for flying military aircraft than ordinary bulky human beings. At this period, it was possible for the Office of Naval Research, followed by other departments of the military services, to rely on the ignorance in Congress and among their military bosses of the relationship between discovery and applicationtenuous as it is--to ensure that the shallowest excuses for supporting basic science would be sufficient. To be sure, these generous agencies were able to justify their openhandedness to themselves by the argument that the money was being spent in the national interest, in the cause of helping university departments and other institutions to be strong. By the time that $\mathrm{Mr}_{r}$ Robert McNamara launched his Project Themis in the mid-1960s, with the objective of giving strictly institutional support and not support for particular research projects to university departments with promise of one kind or another, times had changed. The National Science Foundation was stronger, and there was more reason to suspect that the scale of intellectual effort in basic science was enough to sustain itself. By 1970, the climate had changed so much that Senator Mansfield was able to add to the Military Services legislation a requirement that the Pentagon should spend money on basic research only when this could be seen to be directly relevant to military development. AJthough this has been amended military expenditure on basic science is now a less important part of the whole in the United States than it has ever been.

What are the consequences? The most awkward change has been a diminution of the scale of support for basic science in the United States. The budget of the National Science Foundation has grown in the past few years, but not enough to compensate for the extent to which the Department of Defense and the other agencies of the United States government have been compelled to trim their sails. To make things worse, the foundation has, off its own bat, set out to invest more of its funds in programmes related to technological development than it has yet been able to demonstrate that it can usefully spend. In the long run, the effects of the present strained circumstances of American universities will leave a permanent mark on the development of American science, even though it may in the more immediate future be something of an advantage that "fat" as it is called will be excised from the system. It is less important that the new balance of expenditure will reduce the extent to which applicants for grants for scientific research can hope to play off one agency against another. It has never been a welcome feature of the American system that less good grant applications could bounce from one committee to another until, sometimes by chance, they found a welcome.

\section{Years Ago}

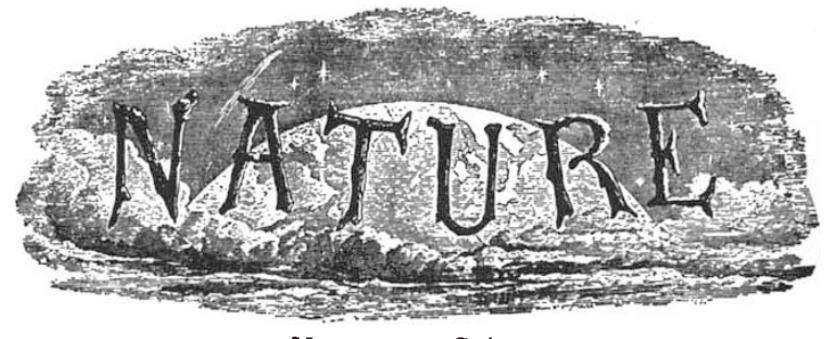

Newspaper Science

TH: general public cannot fail to acquire some very extraordinary as well as crroneoss ro:icns about many subjects re. lating to the progress and application of the different branches of Natural Science, if we are to jucl; $\mathrm{c}$ from sundry scraps of information, daily communicated or reproduced for their instruc. tion, in the columns of even the most influential newspapers. Amongst recent cxamples of this style style of information we might refer to the following :-

Ciestraphy.-Cinder the heading, "Oysters from South America," we find in the Time's of May 16, the aunouncement that the steamer K"ifjir riu had last Sunday " arrived at Hull from Norfolk, Virginia, having on board a cargo consisting of 500 or 600 tons of oysters, \&c."

Mitallurgy. The Enginicr of April 12, in a paragraph on early iron making at Merthyr Tydvil, in South Wales, must. rather astonish metallurgists by writing of "bonts supplying sulphate of lime "in the process.

Architictur:- - In a some what elaboratc article on the new so. called Selenitic mo:tar, which in reality takes its name from the introduction of a little sulphate of lime, which when nativis forms the mineral called selenite in its manufacture, we are informed that " the name given to the improved mortar inclicates to a certain extent the nature of the improvemeut; that it is in the direction of combining selmious acid with a base," \&c. It would, indeed, be good tidings to chemists to find that selenious acid had become so cheap as to allow of its being used for sucl purposes; unfortunately, however, the last price lists inform us that selenium, from which it is made, still costs three shillings per drachm.

From Nature, 6, 60, May 23, 1872. 